\title{
Effect of castration and vitamin E supplementation on carcass and meat quality of Santa Inês lambs
}

\author{
Efecto de la castración y de la suplementación con vitamina E sobre la canal y la calidad de la carne de \\ corderos Santa Inês
}

Efeito da Castração e da suplementação de vitamina E sobre a carcaça e qualidade da carne de ovinos

Santa Inês

\begin{abstract}
André Torres-Geraldo $^{* *}$ (D); Mauro Sartori-Bueno ${ }^{1}$ (D); Ricardo Lopes-Dias-da-Costa ${ }^{1}$ (D); Marcia-Mayumi

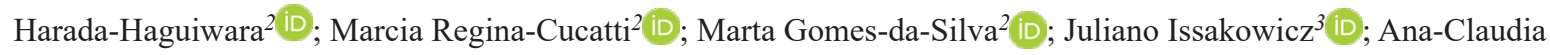

Kocci-Sampaio $^{3}$ (D); Suzana Eri-Yotsuyanagit ${ }^{4}$ Celia Raquel-Quirino ${ }^{5}$ (D).
\end{abstract}

${ }^{1}$ Instituto de Zootecnia, Nova Odessa, São Paulo, Brazil.
${ }^{2}$ Instituto de Tecnologia de Alimentos, Campinas, São Paulo, Brazil.
${ }^{3}$ Centro de Energia Nuclear na Agricultura, Universidade de São Paulo, Piracicaba, São Paulo, Brazil.
${ }^{4}$ Universidade de São Paulo, Escola Superior de Agricultura, Departamento de Agroindústria, Alimentos e Nutrição, Piracicaba, Brasil.
${ }^{5}$ Universidade Estadual do Norte Fluminense Darcy Ribeiro, Campos dos Goytacazes. Rio de Janeiro, Brazil.

To cite this article:

Torres-Geraldo A, Sartori-Bueno M, Lopes-Dias da Costa R, Harada-Haguiwara MM, Regina-Cucatti M, Gomes-da Silva M, Issacowicz J, Kocci-Sampaio AC, Eri-Yotsuyanagi S, Quirino CR. Effect of castration and vitamin E supplementation on carcass and meat quality of Santa Inês lambs. Rev Colomb Cienc Pecu 2020; 33(2):96-109. DOI: https://doi.org/10.17533/udea.rccp.v33n2a02

\begin{abstract}
Background: Carcass and sheep meat quality are influenced by several factors, such as race, age, slaughter weight, type of diet, and dietary supplementation. Objective: To evaluate the effect of castration and vitamin E supplementation on performance, carcass characteristics and meat of lambs slaughtered at $45 \mathrm{~kg}$. Methods: Thirty-two male lambs (16 castrated and 16 not castrated) were fed diets with or without the inclusion of vitamin E. The animals had an average age of $180 \pm 20$ days and a mean weight of $25.1 \pm 4.6 \mathrm{~kg}$. Performance was evaluated for 56 days, and the animals were slaughtered when reaching a weight of $45 \mathrm{~kg}$. The experimental design was randomized blocks based on initial weights, and variables were assessed by a 2x2 factorial design (castrated and intact, supplemented or not with vitamin E, with a probability of 5\%). Results: Higher proportion $(p<0.05)$ of visceral fat was found in castrated animals (kidney: $2.45 \%$, inguinal: $0.57 \%$ and omental: $4.96 \%$ ) than in intact animals (kidney: $1.25 \%$, inguinal $0.27 \%$. and omental $3.12 \%$ ). The aged meat samples showed no color differences for any of the treatments, but there were differences in shear force for steaks aged for 7 days, where the castrated animals showed an average of $2.64 \mathrm{kgf}$ and intact animals showed an average $3.29 \mathrm{kgf}$. The animals supplemented with vitamin E had lower shear forces in non-aged samples. Conclusion: Castration increased deposition of visceral and fat coverage but did not influence the cut yields and total carcass yield. The animals supplemented with vitamin $\mathrm{E}$ had lower shear forces in non-aged samples.
\end{abstract}

Keywords: aged meat; $\alpha$-tocopherol; carcass yield; carcass traits; castration; lamb; lipid oxidation; meat; meat maturation; meat quality; ovine; Santa Ines breed; shear force; sheep; vitamin E.

Received: February 19, 2018; accepted: September 7, 2019

*Corresponding Author. Instituto de Zootecnia, Nova Odessa, São Paulo, Brazil. Tel.: +55 22 99954-3154. Email: andre atg@hotmail.com 


\section{Resumen}

Antecedentes: La calidad de la canal y de la carne de ovino puede ser influenciada por varios factores, como raza, edad, peso de sacrificio, tipo de dieta y suplementación. Objetivo: Evaluar el efecto de la castración y de la suplementación con vitamina E sobre el desempeño, la calidad de la canal y la carne de corderos Santa Inés sacrificados a los $45 \mathrm{~kg}$ de peso. Métodos: Fueron utilizados treinta y dos corderos: dieciséis castrados y dieciséis no castrados, alimentados con dietas con o sin inclusión de vitamina E. Los animales tenían una edad promedio de $180 \pm 20$ días y un peso promedio de $25,1 \pm 4,6 \mathrm{~kg}$. Fue evaluado el desempeño durante 56 días y, al llegar a los $45 \mathrm{~kg}$ de peso fueron sacrificados. El diseño experimental fue en bloques aleatorizados con base en el peso inicial, y las variables analizadas mediante un modelo factorial $2 \times 2$ (castrado o no castrado y suplementado o no con vitamina E, con una probabilidad del 5\%). Resultado: Se encontró mayor proporción $(\mathrm{p}<0,05)$ de grasa visceral en los animales castrados (renal: $2,45 \%$; inguinal: $0,57 \%$ y mesentérica: $4,96 \%$ ) que en los no castrados (renal: 1,25\%; inguinal 0,27\% y mesentérica: 3,12\%). Las muestras de carne maduradas no presentaron diferencias de color entre tratamientos, sin embargo hubo diferencias en la fuerza de corte para las carnes maduradas por 7 días, donde los animales castrados presentaron una media de 2,64 kgf y los no castrados de 3,29 kgf. La carne de los animales suplementados con vitamina $\mathrm{E}$ tuvo menor fuerza de corte en las muestras no maduradas. Conclusión: La castración aumentó la deposición de grasa visceral y de cobertura pero no influenció las características de rendimiento total de la canal y cortes. Los animales suplementados con vitamina $\mathrm{E}$ tuvieron menor fuerza de corte en las muestras no maduradas.

Palabras clave: $\alpha$-tocopherol; características de la canal; calidad de carne; carne; carne madurada; castración; cordero; ovejas; ovinos; oxidación lipídica; raza Santa Ines; rendimiento en canal; resistencia de corte; vitamina E.

\section{Resumo}

Antecedentes: A qualidade da carcaça e da carne ovina pode ser influenciada por vários fatores como raça, idade, peso de abate tipo de dieta e suplementação. Objetivo: Avaliar o efeito da castração e da suplementação de vitamina E sobre o desempenho e qualidade de carcaça e carne de cordeiros Santa Inês abatidos a $45 \mathrm{~kg}$ de peso. Métodos: Foram utilizados trinta e dois cordeiros, dezesseis castrados e dezesseis não castrados alimentados com dietas com ou sem inclusão de vitamina E. Os animais tinham idade média de $180 \pm 20$ dias e peso médio de $25,1 \pm 4,6 \mathrm{~kg}$. Foi avaliado o desempenho durante 56 dias, e ao chegarem aos $45 \mathrm{~kg}$ foi realizado o abate. $\mathrm{O}$ delineamento experimental foi em blocos ao acaso, com base no peso inicial, e as variáveis analisadas por modelo fatorial $2 \times 2$ (castrado ou não castrado e suplementado ou não com vitamina $\mathrm{E}$, ao nível de $5 \%$ ). Resultado: Foi encontrada maior proporção $(\mathrm{p}<0,05)$ das gorduras viscerais nos animais castrados (renal: $2,45 \%$; inguinal: 0,57\% e omental: 4,96\%) do que nos animais não castrados (renal: 1,25\%; inguinal 0,27\% e omental: $3,12 \%$ ). As amostras maturadas não apresentaram diferenças de cor entre os tratamentos, no entanto houve diferenças na força de cisalhamento para as carnes maturadas por 7 dias, na qual os animais castrados apresentaram média de 2,64 kgf e os não castrados de 3,29 kgf. Os animais suplementados com vitamina E apresentaram menores forças de cisalhamento nas amostras não maturadas. Conclusão: A castração aumentou a deposição de gorduras viscerais e de cobertura, mas não influenciou as características de rendimento de carcaça e cortes. Os animais suplementados com vitamina E tiveram menor força de cisalhamento nas amostras não maturadas.

Palavras-chave: $\alpha$-tocopherol; características do canal; carne; carne maturada; castração; cordeiro; força de cisalhamento; maturação; ovelhas; ovinos; oxidação lipídica; raça Santa Inês; rendimento de carcaça; vitamina E. 


\section{Introduction}

Lipid oxidation (oxidative rancidity) is the main factor causing deterioration of meat quality products. As a direct result, several changes such as deterioration in color and flavor, as well as reduction of water and oxidation of cholesterol retention capacity, can occur in fresh, frozen, and processed meat products. Vitamin $\mathrm{E}$ is the most important fat-soluble antioxidant in biological systems, able to interrupt the chain of lipid oxidation in cell membranes. When provided to animals in feed, it gets deposited into cell membranes and subcellular fractions of muscle and adipose tissue, preventing the formation of lipid hydroperoxides, which are degradation products that cause deterioration of odor and flavor (Liu et al., 1995).

The quality of lamb carcasses can be influenced by factors such as breed, age, slaughter weight, and sex, among other factors. In general, young animal carcasses have better meat quality (Pinheiro et al., 2009), but there is an increasing demand for larger frame sizes to obtain specialized cuts (sirloin, French carré, boneless loin, and tenderloin).

Producers prefer male lambs due to greater weight gain and lower fat deposition in the carcass (Burin, 2016). However, the meat from intact animals can show a loss in sensory quality due to factors connected to the presence of testicular hormones, particularly testosterone. Castration is intended to control these traits that influence meat quality, as well as to facilitate handling and prevent odors subsequent from male hormones in the meat of rams slaughtered at older ages (Teixeira et al., 2010).

Therefore, this study aimed to evaluate the effect of castration and vitamin E supplementation on performance, carcass characteristics and meat of lambs slaughtered at $45 \mathrm{~kg}$.

\section{Materials and Methods}

\section{Ethical Considerations}

This study was approved by the Institute's ethics committee on the use of animals for experimentation (no. 180/2013).

\section{Animals, installations and treatments}

The study was conducted at the Sheep Unit of Centro de Pesquisa em Zootecnia Diversificada, located in the city of Nova Odessa, São Paulo, Brazil $\left(22^{\circ} 42^{\prime} \mathrm{S}\right.$ and $47^{\circ} 18^{\prime}$ ' $\left.\mathrm{W}\right)$.

Thirty-two male lambs of the Santa Inês breed were used with an initial age of $180 \pm 20$ days and an initial weight of $25.1 \pm 4.6 \mathrm{~kg}$. They were blocked by initial weight and distributed into four groups: castrated (16 animals) and intact (16 animals), receiving or not receiving vitamin $\mathrm{E}$ ( $\alpha$-tocopherol acetate) at a concentration of $350 \mathrm{mg} / \mathrm{kg}$ dietary dry matter (Kasapidou et al., 2012).

The animals were housed in individual suspended stall with slatted wood floors, $1.2 \mathrm{~m}$ x 2.0 $\mathrm{m}$, with feeding trough and drinking fountain. An adaptation period of 14 days before the start of the experiment was established. The diet was formulated to meet the requirement for a gain of 250-300g/day for lambs of late maturity, according to the NRC (Nutrient Requirements of Small Ruminants: Sheep, Goats, Cervids, and New World Camelids; 2007). The diet was composed of corn silage and concentrated ration based on milled corn, soybean meal, mineral mixture for sheep and calcitic limestone, with a concentrate: roughage ratio around 60:40 (Table 1).

The amount of feed was adjusted biweekly according to the weight of the animals anticipating $10 \%$ of leftovers, so as to not restrict peak consumption. Food leftovers were collected daily throughout the experimental period to obtain a composite sample from each animal. The feed samples (concentrated feed and silage) were collected weekly, stored in plastic bags and then homogenized to form composite samples for the entire experimental period. Samples were oven-dried at $55{ }^{\circ} \mathrm{C}$ for 72 hours to constant weight, then ground in a Wiley mill (TE-680, Piracicaba, São Paulo, Brazil) equipped with a 2 $\mathrm{mm}$ mesh sieve for removal of a sub-sample for chemical-bromatological analysis according to AOAC (CHEMISTS, 1995). 
Table 1. Proportion of ingredients and chemical composition of corn silage and concentrate ration.

\begin{tabular}{ccc}
\hline Ingredients & $\begin{array}{c}\text { Concentrated } \\
\text { Proportion of Ingredients (\%) }\end{array}$ & Corn silage \\
\hline Corn & 71.4 & - \\
Soybean meal & 25.0 & - \\
Mineral mix* & 1.3 & - \\
Sodium chloride & 0.7 & - \\
Calcitic limestone & 1.6 & - \\
\hline Chemical composition & & \\
\hline DM (\%) & 84.4 & 22.1 \\
CP (\%) & 22.3 & 7.9 \\
EE (\%) & 2.60 & 3.2 \\
NDF (\%) & 20.38 & 62.6 \\
ADF (\%) & 3.82 & 31.9 \\
MM (\%) & 6.20 & 5.8 \\
Hem (\%) & 16.7 & 30.3 \\
\hline
\end{tabular}

$\mathrm{DM}=$ dry matter; $\mathrm{CP}=$ crude protein; $\mathrm{EE}=$ ethereal extract; $\mathrm{NDF}=$ neutral detergent fiber; $\mathrm{ADF}=$ acid detergent fiber; $\mathrm{MM}=$ mineral matter; Hem = hemicellulose. * Product composition: calcium $120.00 \mathrm{~g} / \mathrm{kg}$; phosphorus $87.00 \mathrm{~g} / \mathrm{kg}$; sodium $147.00 \mathrm{~g} / \mathrm{kg}$; sulfur $18.00 \mathrm{~g} / \mathrm{kg}$; copper $590.00 \mathrm{mg} / \mathrm{kg}$; cobalt $40.00 \mathrm{mg} / \mathrm{kg}$; chromium $20.00 \mathrm{mg} / \mathrm{kg}$; iron 1,800.00 mg/Kg; iodine $80.00 \mathrm{mg} / \mathrm{kg}$; manganese $1,300.00 \mathrm{mg} / \mathrm{kg}$; selenium $15.00 \mathrm{mg} / \mathrm{kg}$; zinc 3,800.00 mg/kg; molybdenum $300.00 \mathrm{mg} / \mathrm{Kg}$; fluorine (max.) $870.00 \mathrm{mg} / \mathrm{Kg}$.

\section{Performance}

The animals were weighed (Toledo MGR400, São Bernardo do Campo, São Paulo, Brazil) at the beginning of the experiment (after the adaptation period) and every 14 days until completing 56 days of confinement. All weighing was done in the morning prior to feed delivery. Total live weight gain (LWG) and average daily gain (ADG) were calculated. The dry matter intake (DMI) for each animal was obtained by the difference between the amount of dry matter (DM) of the feed provided and the amount of DM in the leftovers. This variable was expressed in grams per day (g/day), in relation to the metabolic weight ( $\mathrm{g} / \mathrm{kg} \mathrm{LW0.75),} \mathrm{and} \mathrm{in}$ relation to the percentage of live weight $(\% \mathrm{LW})$.

Before slaughter, solid feed fasting was imposed for 24 hours, after which the animals were weighed to obtain final live weight (LWf) before shipment. The slaughtering was carried out according to the standard called Industrial Regulation and Sanitary Inspection for Animal
Origin Products (RIISPOA), issued by Brazilian legislation (Decree $\mathrm{n}^{\mathrm{o}}$ 9013/17). During evisceration, the non-carcass components were separated and weighed.

The carcasses were weighed immediately after slaughter to obtain hot carcass weigh (HCW) and were stored in a cold room at 7 ${ }^{\circ} \mathrm{C}$ for 24 hours to obtain cold carcass weight (CCW). Measurements of leg length (LL), leg circumference (LC), chest circumference (CC), hip circumference (HC), and chest depth (CD) were obtained using a measuring tape.

Measurements of the Longissimus dorsi muscle area and the subcutaneous fat thickness were performed in the region between the 12th and 13 th ribs. The loin eye area was drawn on parchment paper and determined using the System for Root and Soil Coverage Analysis (SIARCS®) (Embrapa, São Carlos, SP, Brazil, version 3.0). For the subjective evaluation of fat cover, a scale of 5 points was opted, 1 for excessively lean and devoid of fat cover and 5 
for excessively fat. For conformation, a scale of 1 to 5 was also used, with value 1 attributed to very poor and 5 to excellent conformation (Cunha et al., 2007).

To obtain the weight of meat cuts, the left half carcass was sectioned in the following cuts: neck, chop, rack, square-cut shoulder, flank, shoulder, rib, leg, loin, tenderloin and rump.

\section{Physicochemical assays}

The color was determined in the Longissimus dorsi muscle with a colorimeter (Minolta, CM600d- Osaka, Japan), in a CIELAB system (MacDougall, 1994), which evaluates the parameters L* (luminosity), a* (red content), and $b^{*}$ (yellow content). The values $L^{*}, a^{*}$ and $b^{*}$ were obtained at three different points on the muscle surface to obtain mean values (Komiyama et al., 2009).

Four samples (steaks) with a thickness of 2 $\mathrm{cm}$ were removed from the Longissimus dorsi, weighed and baked on an industrial plate until reaching internal temperature of $75^{\circ} \mathrm{C}$. After cooking, steaks were kept at room temperature until reaching internal temperature of $40{ }^{\circ} \mathrm{C}$ and again weighed for calculation of weight loss by baking. The shear force evaluation was conducted on the same samples used to calculate weight loss by cooking (WLC). Cylinders of $1.27 \mathrm{~cm}$ in diameter were taken in the direction of the muscle fibers. With the help of a cylindrical mold, three cylinders of each piece of the muscle were removed and placed in a texture-meter (TA-XT $2 \mathrm{i}$ Texture Technologies Corp., NY, USA), coupled to a Warner Bratzler blade (1 mm thickness, GR Electrical Manufacturing Co., Manhattan, KS, USA). The equipment was calibrated to a standard weight of $5 \mathrm{~kg}$. The rate of descent of the device was $200 \mathrm{~mm} / \mathrm{min}$ (AMSA, 1995). The final value was taken as the mean of 12 readings per sample, expressed in kilograms of force (kgf). (AMSA, 1995).

For water holding capacity (WHC), the method proposed by Hamm (1960) was used.
The concentration of vitamin E contained in the Longissimus dorsi muscle was measured in the samples of four animals from each treatment, using the method proposed by Brubacher et al. (1985). The centesimal analyzes methodology were performed in triplicate and according to the methodology described by Cecchi (1999), and AOAC (2000).

\section{Matured meat assays}

The right side of Longissimus dorsi muscle was removed and separated into three equal parts, distributed between three maturation times: 0, 7 and 14 days. Samples were vacuum packed and maintained at $2{ }^{\circ} \mathrm{C}$ in a BOD (CIENLAB, CE- 300/350 Campinas, SP, Brazil) chamber until analysis. Analyses of color, weight loss by cooking and shear force were performed in the samples. The analysis of 2-thiobarbituric acid (TBA) was performed according to the method proposed by Koniecko (1985).

\section{Experimental design and statistical analysis}

A randomized block with $2 \times 2$ factorial design (castrated or intact, with or without vitamin E supplementation) was used, with eight animals per treatment. The variables studied were subjected to analysis of variance at $5 \%$ significance by means of the General Linear Models Procedure (PROC GLM) of the Statistical Analysis System (SAS/STAT, 2003, Version 9.1). The least squares method was used to obtain the means of the treatments, which were compared by the Tukey test. As no effect of the interaction between the factors for any studied variable was observed, this was removed from the statistical model.

\section{Results}

There was no difference $(p>0.05)$ for the variables IW, FW, ADG and FC (Table 2). 
Table 2. Performance of Santa Ines lambs, castrated, intact, supplemented or not with vitamin E.

\begin{tabular}{lccccccc}
\hline & \multicolumn{2}{c}{ Category } & p & \multicolumn{2}{c}{ Vitamin E } & p & MSE \\
\hline & Intact & $\mathbf{C}$ & & $\mathbf{S}$ & NS & & \\
IW (Kg) & 26.09 & 24.11 & 0.313 & 26.03 & 24.17 & 0.342 & 1.914 \\
FW (kg) & 40.71 & 37.61 & 0.153 & 40.30 & 38.03 & 0.297 & 2.087 \\
ADG (g/day) & 261 & 241 & 0.353 & 255 & 247 & 0.689 & 0.020 \\
FC (KgDM/Kg gain) & 4.56 & 4.53 & 0.940 & 4.58 & 4.51 & 0.850 & 0.358 \\
\hline
\end{tabular}

$\mathrm{IW}=$ initial live weight; $\mathrm{FW}=$ final live weight; $\mathrm{ADG}=$ average daily gain; $\mathrm{FC}=$ feed conversion; $\mathrm{C}=$ castrated; $\mathrm{S}=$ supplemented with vitamin E; NS = not supplemented. MSE = mean standard error. Averages compared by the F test at 5\% probability. $p=$ differences in parameters between treatments.

There was no difference $(\mathrm{p}>0.05)$ for the variables conformation (CONF), fat cover (FT), hip circumference (HC), internal length (IL), leg length (LL), leg circumference (LC), chest depth (CD) and chest length (CL). FT was higher $(\mathrm{p}<0.05)$ in castrated animals. Carcass yields (WCY -warm carcass yield-, CCY -cold carcass yield (CCY-) were similar $(\mathrm{p}>0.05)$ between treatments. The non-supplemented animals showed larger loin eye area than the supplemented ones (Table 3).

No difference $(\mathrm{p}>0.05)$ was found between supplementation and castration for the weight of blood, paws, GTf (gastrointestinal tract full), GTe (gastrointestinal tract empty) and kidneys. Larger weights and head proportions were found in intact animals in relation to castrated animals $(p<0.05)$. Thoracic organ weights were higher $(p<0.05)$ in intact animals. Fat weight (renal, inguinal and omental) was higher $(p<0.05)$ in castrated animals in relation to the intact ones. Supplementation with vitamin E did not influence the weights of non-carcass constituents. There was a statistical difference $(p<0.05)$ only in the liver proportion, which was higher in supplemented animals than in the nonsupplemented animals (Table 4).

Table 3. Carcass yields of Santa Ines lambs, castrated or intact, supplemented or not with vitamin E.

\begin{tabular}{lccccccc}
\hline & \multicolumn{2}{c}{ Category } & $\mathbf{p}$ & \multicolumn{2}{c}{ Vitamin E } & p & MSE \\
\hline & Intact & $\mathbf{C}$ & & $\mathbf{S}$ & $\mathbf{N S}$ & & \\
REA carcass (cm2) & 16.5 & 15.2 & 0.070 & 15.05 & 16.6 & 0.030 & 0.50 \\
FT carcass (cm) & 1.40 & 1.79 & 0.04 & 1.58 & 1.61 & 0.894 & 0.174 \\
Conformation (1-5) & 2.09 & 1.89 & 0.127 & 1.89 & 2.09 & 0.127 & 0.125 \\
FT (1-5) & 2.87 & 1.79 & 0.374 & 2.82 & 1.84 & 0.418 & 1.17 \\
SW (kg) & 43.58 & 43.32 & 0.778 & 43.00 & 43.90 & 0.330 & 0.886 \\
HCW (kg) & 21.70 & 21.90 & 0.685 & 21.38 & 22.22 & 0.107 & 0.496 \\
CCW (kg) & 21.08 & 21.35 & 0.604 & 21.20 & 21.23 & 0.956 & 0.508 \\
WCY (\%) & 49.78 & 50.58 & 0.237 & 49.74 & 50.62 & 0.191 & 0.645 \\
CCY (\%) & 48.39 & 49.27 & 0.208 & 49.30 & 48.36 & 0.184 & 0.675 \\
\hline
\end{tabular}

Rib eye area (REA), fat thickness (FT), slaughter weight (SW), hot carcass weight (HCW), cold carcass weight (CCW), cold carcass yield (CCY) and warm carcass yield (WCY). $\mathrm{C}=$ castrated; $\mathrm{S}=$ supplemented with vitamin $\mathrm{E}$; $\mathrm{NS}=$ not supplemented. $\mathrm{MSE}=$ mean standard error. Averages compared by the $\mathrm{F}$ test as $5 \%$ probability. $\mathrm{p}=$ differences in parameters between treatments. 
Table 4. Weights of non-carcass components (NC) of Santa Ines lambs, castrated, intact, supplemented or not with vitamin $\mathrm{E}$.

\begin{tabular}{cccccccc}
\hline & \multicolumn{2}{c}{ Category } & p & \multicolumn{2}{c}{ Vitamin E } & p & MSE \\
\hline & Intact & $\mathbf{C}$ & & $\mathbf{S}$ & NS & & \\
$\mathrm{NC}(\mathrm{kg})$ & 8.15 & 9.65 & 0.0001 & 8.96 & 8.90 & 0.999 & 0.103 \\
$\mathrm{GTf}(\mathrm{kg})$ & 8.54 & 8.97 & 0.203 & 8.85 & 8.66 & 0.585 & 0.326 \\
$\mathrm{GTe}(\mathrm{kg})$ & 2.57 & 2.77 & 0.226 & 2.68 & 2.66 & 0.889 & 0.155 \\
Liver $(\mathrm{g})$ & 699 & 719 & 0.580 & 740 & 670 & 0.101 & 0.035 \\
Thoracic organs $(\mathrm{kg})$ & 1.08 & 1.20 & 0.012 & 1.14 & 1.14 & 0.929 & 0.042 \\
Kidneys $(\mathrm{g})$ & 116 & 160 & 0.420 & 114 & 160 & 0.390 & 0.054 \\
Renal fat $(\mathrm{Kg})$ & 0.548 & 1.071 & 0.001 & 0.808 & 0.810 & 0.985 & 0.085 \\
Inguinal fat $(\mathrm{g})$ & 119 & 248 & 0.001 & 172 & 190 & 0.354 & 0.023 \\
Omental fat $(\mathrm{kg})$ & 1.37 & 2.15 & 0.002 & 1.80 & 1.72 & 0.729 & 0.230 \\
\hline
\end{tabular}

GTf (gastrointestinal tract full), GTe (gastrointestinal tract empty). C= castrated; S= supplemented with vitamin E; NS= not supplemented. MSE $=$ mean standard error. Averages compared by the $\mathrm{F}$ test at $5 \%$ probability. $\mathrm{p}=$ differences in parameters between treatments.

The weight of the neck and tenderloin were influenced $(p<0.05)$ by the castration, being superior in the intact animals. The loin weight was higher $(\mathrm{p}<0.05)$ in the animals that received vitamin supplementation.

For the weights of shoulder, leg, breast, rib, chop, rack, square cut shoulder and rump, no significant differences were found in relation to supplementation and category $(\mathrm{p}>0.05)$ (Table 5).
Table 6 shows that the color parameters $\left(\mathrm{L}^{*}\right.$, $\left.a^{*}, b^{*}\right)$ were similar for all treatments and no statistical differences were found $(p<0.05)$ at any of the maturation times. The shear force was lower $(p<0.05)$ in the animals supplemented with vitamin $\mathrm{E}$ in the non-mature samples, but no differences were found in the meat matured for 7 and 14 days between treatments. Results in the baking loss analyses were similar between the treatments, with no difference between maturation times $(p<0.05)$.

Table 5. Weights of meat cuts of Santa Ines lambs, castrated or intact, supplemented or not with vitamin E.

\begin{tabular}{cccccccc}
\hline & \multicolumn{2}{c}{ Category } & p & \multicolumn{2}{c}{ Vitamin E } & p & MSE \\
\hline & Intact & $\mathbf{C}$ & & $\mathbf{S}$ & NS & & \\
Neck (kg) & 1.23 & 1.10 & 0.004 & 1.18 & 1.15 & 0.468 & 0.531 \\
Shoulder (kg) & 1.76 & 1.72 & 0.290 & 1.73 & 1.76 & 0.528 & 0.284 \\
Leg (kg) & 3.19 & 3.20 & 0.900 & 3.16 & 3.22 & 0.441 & 0.593 \\
Loin (kg) & 0.79 & 0.77 & 0.575 & 0.74 & 0.82 & 0.035 & 0.287 \\
Rib (kg) & 1.24 & 1.37 & 0.177 & 1.30 & 1.31 & 0.921 & 0.936 \\
Chop (kg) & 1.79 & 1.63 & 0.102 & 1.61 & 1.80 & 0.061 & 0.618 \\
Tenderloin (g) & 0.14 & 0.12 & 0.027 & 122 & 140 & 0.066 & 0.293 \\
Square Shoulder (kg) & 770 & 702 & 0.199 & 723 & 763 & 0.430 & 0.210 \\
Rack (kg) & 1.03 & 0.95 & 0.121 & 0.95 & 1.03 & 0.106 & 0.792 \\
Rump (kg) & 0435 & 418 & 0.638 & 461 & 389 & 0.136 & 0.422 \\
\hline
\end{tabular}

$\mathrm{C}=$ castrated; $\mathrm{S}=$ supplemented with vitamin $\mathrm{E} ; \mathrm{NS}=$ not supplemented. $\mathrm{MSE}=$ mean standard error. Averages compared by the $\mathrm{F}$ test with $5 \%$ probability. $\mathrm{p}=$ differences in parameters between treatments. 
Table 6. Color, shear force (SF) and weight loss from cooking (WLC) for samples aged 0, 7 and 14 days of Santa Ines lambs, castrated or intact, supplemented or not with vitamin E.

\begin{tabular}{|c|c|c|c|c|c|c|c|}
\hline & \multicolumn{2}{|c|}{ Category } & \multirow[t]{2}{*}{$\mathbf{p}$} & \multicolumn{2}{|c|}{ Vitamin E } & \multirow[t]{2}{*}{ p } & \multirow[t]{2}{*}{ MSE } \\
\hline & Intact & C & & $\mathbf{S}$ & NS & & \\
\hline \multicolumn{8}{|c|}{0 Days } \\
\hline $\mathrm{L}^{*}$ & 32.8 & 31.5 & 0.273 & 31.4 & 32.9 & 0.197 & 0.829 \\
\hline$a^{*}$ & 15.0 & 15.3 & 0.526 & 15.6 & 14.6 & 0.100 & 0.420 \\
\hline$b^{*}$ & 6.36 & 5.81 & 0.778 & 6.24 & 5.93 & 0.874 & 1.380 \\
\hline SF kgf & 4.24 & 3.79 & 0.128 & 3.64 & 4.39 & 0.016 & 0.202 \\
\hline WLC & 25.7 & 25.9 & 0.925 & 26.3 & 25.3 & 0.410 & 0.834 \\
\hline \multicolumn{8}{|c|}{7 days } \\
\hline $\mathrm{L}^{*}$ & 36.1 & 35.0 & 0.440 & 36.0 & 35.2 & 0.560 & 0.962 \\
\hline$a^{*}$ & 14.6 & 15.5 & 0.386 & 15.4 & 14.7 & 0.524 & 0.697 \\
\hline$b^{*}$ & 8.37 & 8.28 & 0.900 & 8.94 & 7.71 & 0.122 & 0.529 \\
\hline SF kgf & 3.29 & 2.64 & 0.007 & 3.08 & 2.85 & 0.294 & 0.202 \\
\hline WLC & 33.8 & 32.2 & 0.600 & 34.9 & 31.2 & 0.252 & 3.070 \\
\hline \multicolumn{8}{|c|}{14 Days } \\
\hline $\mathrm{L}^{*}$ & 36.9 & 34.7 & 0.214 & 36.1 & 35.5 & 0.726 & 1.180 \\
\hline$a^{*}$ & 14.8 & 15.9 & 0.056 & 15.2 & 15.5 & 0.505 & 0.390 \\
\hline$b^{*}$ & 8.98 & 8.78 & 0.794 & 9.05 & 8.71 & 0.655 & 0.543 \\
\hline SF kgf & 3.24 & 2.59 & 0.070 & 2.59 & 3.24 & 0.070 & 0.331 \\
\hline WLC & 32.5 & 30.9 & 0.570 & 32.1 & 31.3 & 0.795 & 2.850 \\
\hline
\end{tabular}

Lightness $\left(\mathrm{L}^{*}\right)$; intensity of yellow $\left(\mathrm{a}^{*}\right)$; intensity of green $\left(\mathrm{b}^{*}\right)$; shear force (SF); weight loss from cooking (WLC); $\mathrm{C}=$ castrated; $\mathrm{S}=$ supplemented with vitamin $\mathrm{E} ; \mathrm{NS}=$ not supplemented. $\mathrm{MSE}=$ mean standard error. Averages compared by the $\mathrm{F}$ test at $5 \%$ probability. $\mathrm{p}=$ differences in parameters between treatments.

No difference $(p<0.05)$ was found for any of the treatments in relation to the centesimal analysis. Water-holding capacity (WHC) was not different $(\mathrm{p}>0.05)$ in any of the treatments.

The TBA for day 0 and day 14 was not influenced by castration and vitamin $\mathrm{E}$ supplementation. The vitamin concentration in the Longissimus dorsi muscle was similar $(p>0.05)$ for all treatments.

\section{Discussion}

Several factors can affect lambs weight gain and performance, such as genotype, sex, type of birth and nutrition. Differences in lamb performance are also reported, when comparing different castration methods with animals of different genotypes, slaughtered between 30 and $32 \mathrm{~kg}$ live weight (Osório et al., 1999;
Ribeiro et al., 2003). Although Rodríguez and Castells (1991) report greater weight gain in intact animals, we found no differences between treatments for performance variables. Although Rodríguez and Castells (1991) reported higher weight gain in intact animals, we found no differences between treatments for the performance variables.

Vitamin E supplementation also did not alter the performance variables. These findings corroborate the observations of Pinto et al., (2011), who investigated Santa Ines sheep supplemented with $500 \mathrm{mg} /$ head/day of vitamin $\mathrm{E}$ and found no differences in performance variables by the addition of the vitamin. Supplementation can influence performance characteristics when diet levels do not reach the minimum level required for the body to 
perform normal functions. Since within the present work, all diets were balanced to meet the animals needs, no effects were expected on the performance variables.

The results found for ADG can be considered high (Table 2). Silva et al., (2013) worked with Santa Inês lambs and obtained lower values for ADG (44 g/day). The highest values found for ADG in the present study can be attributed to the high concentrate diet used in confinement.

The values found for $\mathrm{FC}$ were higher than those found by Turino et al. (2012), who evaluated the substitution of neutral detergent fiber on the performance of Santa Inês lambs and found values between 3.50 and $3.93(\mathrm{Kg}$ Dry Matter/kg gain). Generally, as lamb ages, the performance traits decrease, lower FC values may have occurred due to older animals used in this experiment.

Low values on conformation and degree of fat coverage reported are characteristic of the Santa Inês breed, which has less muscular carcasses compared to the breeds selected for meat production (Filho et al., 2010). Azeredo et al. (2006) studied sheep in an extensive grazing regime reporting similar values on conformation (2.02 to 2.4). However, on fat thickness, their values were lower (1.4 to 1.9). Discrepancies of FT in the present work may have occurred due to the high concentrate diet used in confinement.

Silva et al., (2013) evaluated the effect of maize corn replacement on nutrient digestibility in the diet and on the performance and carcass traits of Santa Inês sheep at 5 months of age. They reported lower values for warm carcass yield (37-44\%) and cold carcass yield $(35-42 \%)$; this is related to the degree of maturity. Lambs slaughtered at an early age tend to have lower yields than those slaughtered later; this characteristic is usually related to the amount of fat deposited with older age (Galvani et al., 2010).
Greater weights of renal, pelvic and inguinal fat were found in castrated animals, as expected. The increase in the amount of internal fat proves the physiological characteristic of these animals in depositing intra-abdominal fat. Considering that this fat is not used for human consumption, this can be considered wasted food energy (Carvalho et al., 2015).

Ribeiro et al., (2003) and Azeredo et al., (2005) evaluated the weight of non-carcass components in lambs of various castrated and intact genotypes, reporting no differences in the amount of abdominal fat. In the present study, there was an increase, in $\mathrm{kg}$, in non-carcass components, thoracic organs and visceral, renal and inguinal fat in castrated animals. Intact lambs develop faster than spayed lambs, showing greater muscle gain and less fat deposition compared to castrated females and males. This response can be attributed to the action of testicular hormones, especially testosterone (Moletta et al., 2014).

Animal carcasses, especially as they get older, have a strong influence on fat deposition. The low conformation and the degree of fat coverage found in the present study are typical of the Santa Inês breed, which is a breed still in the selection process (Filho et al., 2010).

Liver weight was higher in the supplemented animals, likely because vitamin $E$ is characterized for high hepatic deposition (Chan and Decker, 1994).

Neck weight was greater in intact animals, possibly due to the fact that intact animals tend to deposit more muscle tissue compared to castrated ones, especially in the front muscles, as a characteristic of sexual dimorphism (Padua et al., 2001).

The weight of tenderloin presented significant differences $(p<0.05)$, being heavier in intact males, which may have occurred due to greater muscular deposition in relation to intact animals. The other cuts did not present significant differences, but there was a tendency to be heavier in intact males. 
The values found in the color analysis are similar to those described by Bressan et al. (2002) for Santa Inês lambs, being 31.36 to 38.0 for $\mathrm{L}^{*}$ (luminosity), 12.27 to 18.01 for a* (red content), and 3.34 to 5.65 for $b^{*}$ (yellow content).

Color characteristics in fresh meat were not influenced by supplementation, probably because there was no time for oxygen action. Thus, vitamin E did not play an anti-oxidant role, as also found by Pinto et al. (2011), who evaluated the effect of vitamin E supplementation on lamb meat color and did not find differences in the color variables in relation to the control group. Fuente et al. (2013) evaluated the effect of dietary supplementation with vitamin $\mathrm{E}$ on lambs and found no difference in fresh meat color for both lambs not supplemented and those supplemented with vitamin E.

Lauzurica et al. (2005) observed that initially vitamin E did not affect the color of fresh meat, but maintained the color of meat in later storage periods. In the mature samples, the color was not influenced by the supplementation, possibly because the amount of vitamin $\mathrm{E}$ deposited in the muscle was not adequate to preserve the color. There was no influence of the category on the color characteristics. There was an increase of the variable $b^{*}$ in the mature meat of all the treatments, it is possible this has occurred due to the color change of the meat during the maturation processes.

The lower value of shear force at 7 days may have occurred because castration increases the deposition of intramuscular fat, thus increasing meat tenderness. The same was found by Júnior et al. (2006), who evaluated the shear force of castrated and intact lambs.

The maturation was efficient in increasing the softness. The samples matured for 7 days obtained a shear force $26.15 \%$ lower than those not matured, and the samples matured for 14 days obtained a strength $27.39 \%$ smaller than those not matured.
The values of baking loss were similar to those found by Gonçalves et al. (2004), who evaluated the baking loss of the meat of castrated and intact lambs. There was an increase in water loss values according to maturation time. A prolonged storage period can increase weight loss by cooking, as described by Vergara and Gallego (1999). The samples maturing for 7 and 14 days lost 25.46 and $25.88 \%$ more water, respectively, when compared to fresh meat.

The values of crude protein and ash were in agreement with those found by Pinheiro et al., (2009) and Carvalho and Brochier (2008), who worked with slaughtered lambs with different ages and diets. The higher amount of fat observed in the present study may have occurred because the animals were older at slaughter, and fat deposition is a characteristic of age.

Castration did not influence the centesimal composition of the meat. However, Júnior et al., (2006) evaluated the centesimal composition of ideal mestizo lambs, castrated and intact, slaughtered at $37 \mathrm{~kg}$, and verified a higher amount of fat in castrated animals. These data show that the percentage of intramuscular fat varies according to the category, age, slaughter weight and nutritional levels (Claffey et al., 2018). Although the castrated animals presented higher proportions of visceral fat and cover fat, the results obtained in the centesimal analysis showed that castration was not efficient in the deposition of intramuscular fat.

The values of water retention capacity were similar to those found by Pinheiro et al. (2009), who evaluated the meat quality of lambs fed different concentrate: roughage ratios. Moreno et al. (2011) evaluated the effect of different genotypes on meat characteristics and found average water retention of $60.18 \%$. Adequate water retention capacity, together with intramuscular fat deposition, favors meat tenderness and succulence (Yamamoto et al. 2013). Therefore, higher values of water holding capacity (WHC) can indicate better grades of meat quality. 
TBA values were higher on day 14 than on day 0 . Nieto et al. (2011) evaluated the storage of lamb meat from animals with different diets stored for 2 and 4 days. The authors also verified that the TBA values increased with meat storage, indicating the occurrence of lipid oxidation. However, in this experiment, there was no difference between treatments in the TBA results for day 0 or day 14, which means that vitamin E supplementation was not efficient to decrease the effects of lipid oxidation on lamb meat not matured and matured for 14 days. Supplementation with $350 \mathrm{mg} / \mathrm{kg}$ was not efficient to deposit vitamin $\mathrm{E}$ into muscle, so antioxidant effects were not observed. Castration did not alter the performance, yield and quality of meat and carcass, but it did increase the deposition of visceral fats and fat cover.

In conclusion, vitamin $\mathrm{E}$ supplementation with $350 \mathrm{mg} / \mathrm{kg}$ of dry matter did not promote significant changes in meat quality characteristics. Under the conditions studied, castration and vitamin E supplementation of Santa Inês lambs slaughtered at $45 \mathrm{~kg}$ was not justified.

\section{Declarations}

\section{Funding}

We would like to thank to CAPES/CNPq for the support to conduct the study.

\section{Author contributions}

André T. Geraldo: collected the data; writing.

Mauro S. Buneo: administered the project.

Ricard LD da Costa, Celia R-Quirino Marcia $\mathrm{M}-\mathrm{H}$-Haguiwara: reviewing.

Marcia R-Cucatti, Marta G-da-Silva, Juliano Issacowicz; Ana C-K-Sampaio; Suzana E-Yotsuyanag: Collected the data.

\section{Conflicts of interest}

The authors declare they have no conflicts of interest with regard to the work presented in this report.

\section{References}

AOAC. Association of official analytical cAOAC. Association of official analytical chemists. Gaithersburg (MD): Official methods of analysis of the AOAC International; 2000.

AMSA. Research guidelines for cookery, sensory evaluation and instrumental tenderness measurements of fresh meat. Chicago (IL): American Meat Science Association; 1995.

Azeredo DM, Osório MTM, Osório JC da S, Mendonça G E, Jardim RD, Pouey JLO, Barboza J. Componentes corporais em ovinos corriedale não castrados, castrados e criptorquidas abatidos em diferentes idades. Rev bras agrocienc 2005; 11: 333-338. DOI: http://dx.doi.org/10.18539/cast.v11i3.1272

Bressan MC, Prado OV, Pérez JRO, Lemos ALSC, Bonagurio S. Efeito do peso ao abate de cordeiros santa inês e bergamácia sobre as características físico-químicas da carne. Food Sci Technol 2000; 22: 11-18. DOI: http://dx.doi.org/10.1590/S0101-20612001000300008

Brubacher $\mathrm{G}, \mathrm{Mu}$ LMW. Methods for the Determination of Vitamins in Food. London(UK): Elsevier Applied Science Publishers 1985.

Burin P. Quality of fat sheep: characteristics and influence factors. Rev electrón vet 2016; 17:1-28.

Carvalho S, Brochier MA. Composição tecidual e centesimal e teor de colesterol da carne de cordeiros terminados em confinamento com dietas contendo níveis crescentes de resíduo úmido de cervejaria. Ciênc Rural 2008; 38:2023-2028. DOI: http://dx.doi.org/10.1590/S0103-84782008000700035 
Carvalho ZG, Silva FVE, Araújo AR, Alves DD, Oliveira SLL, Reis ST, Silva VL. Cortes cárneose constituintes não-carcaça de ovelhas terminadas em pasto com teores diferentes de suplementação. Semina: Ciênc Agrár 2015. 36:1:409-420. DOI: http://dx.doi.org/10.5433/1679-0359.2015v36n1p409

Claffey NA, Fahey AG, Gkarane V, Moloney AP, Monahan FJ, Diskin MG. Effect of breed and castration on production and carcass traits of male lambs following an intensive finishing period. Transl Anim Sci 2018:1-21. DOI: https://doi.org/10.1093/tas/txy070

Cecchi HM. Fundamentos teóricos e práticos em análise de alimentos. 1nd ed. Campinas (SP): Editora da Unicamp; 1999.

Chan WK, Decker E. Endogenous skeletal muscleantioxidants. Crit Rev Food Sci Nutr 1994; 34:403-426. DOI: https://doi.org/10.1080/10408399409527669

Cunha EA, Lima JA, Santos LE. Bueno M. Ovinocultura Proceedings of the Simpósio IZ; 2007 Mar 16; São Paulo: Instituto de Zootecnia de São Paulo; 2007.

Filho JTA, CostaRG, Fraga AB, Sousa WH, Cezar MF, Batista AS. Desempenho e composição da carcaça de cordeiros deslanados terminados em confinamento com diferentes dietas. Rev Bras Zootec 2010; 39:1:363-371. DOI: https://dx.doi.org/10.1590/S1516-35982010000200020

Fuente J, Diaz MT, Alvarez I, Lauzurica S, Caneque V, Pérez C, 2013. Effect of dietary supplementation with vitamin $E$ on characteristics of vacuum-packed lamb. Rev Fitoter 2013; 13:125-135. DOI: https://doi.org/10.1002/jsfa.2759

Galvani DB, Pires CC, Wommer TP, Oliveira F, Kodayssi GPT, Griebler L. Postweaning growth of the non-carcass components of Texel crossbred lambs.RevBrasZootec2010;39:1558-1564.DOI: http://dx.doi.org/10.1590/S1516-35982010000700023
Gonçalves LG, Zapata JFF, Rodrigues MDCP, Borges AS. 2004. Efeitos do sexo e do tempo de maturação sobre a qualidade da carne ovina. Food Sci Technol 2004; 24:459-467. DOI: http://dx.doi.org/10.1590/S0101-20612004000300027

Hamm R, Deatherage F. Changes in hydration, solubility and charges of muscle proteins during heating of meat. J Food Sci 1960; 25:587-610. DOI: https://doi.org/10.1111/j.1365-2621.1960. tb00004.x

Júnior MHK, Siqueira ER, Roça RO. Qualidade da carne de cordeiros castrados e nãocastrados confinados sob dois fotoperíodos. Rev Bras Zootec 2006; 35:1872-1879. DOI: http://dx.doi.org/10.1590/S1516-35982006000600040

Kasapidou E, Wood JD, Richardson RI, Sinclair LA, Wilkinson RG, Enser M. Effect of vitamin E supplementationanddietonfattyacidcomposition and on meat colour and lipid oxidation of lamb leg steaks displayed in modified atmosphere packs. Meat Sci 2012; 90:908-916. DOI: http://dx.doi.org/10.1016/j.meatsci.2011.11.031

Komiyama CM, Regina M, Boaro F, Mendes AA. Evaluation of postmortem maturation technic on meat quality and muscle fiber structure of breast meat spent broiler breeder. Food Sci Technol 2009:89-93. DOI: https://dx.doi.org/10.1590/S0101-20612009000100007.

Koniecko ES. Handbook of Meat Analysis. 1nd ed. Mayne, (NJ): Avery Publishing Group, 1985.

Lauzurica S, Fuente J, Díaz MT, Alvares I, Pérez C, Cañeque V. 2005. Effect of dietary supplementation of vitamin E on characteristics of lamb meat packed under modified atmosphere. Meat Sci 2005; 70:639-646. DOI: https://doi.org/10.1016/j.meatsci.2005.02.013

Liu Q, LanariMC, SchaeferD. A review of dietary vitamin E supplementation for improvement of beef quality. J Anim Sci 1995; 73:3131-3140. DOI: https://doi.org/10.2527/1995.73103131x 
MacDougall DB. Colour of meat. In A. M. Pearson, \& T. R. Dutson, Quality attributes and their measurement in meat, poultry and products. Ad in Meat Re Series 1994; 9:79-94.

Moletta JL, Prado IN, Fugita CA, Eiras CE, Carvalho CB, Perotto D. Características da carcaça e da carne de bovinos não-castrados ou castrados terminados em confinamento e alimentados com três níveis de concentrado. Semina: Ciênc Agrár 2014; 35:1035-1050. DOI: https://doi.org/10.5433/1679-0359.2014v35n2p1035

Moreno GMB, Buzzulini C, Borba $\mathrm{H}$, Costa AJ, Lima TMA, Dourado JFB. Effect of genotype and dietary protein level on lamb meat quality. Rev Bras Saúde e Prod Anim 2011; 12:630-640. DOI: https://doi.org/10.1590/S1516-35982003000300027

Nieto G, Estrada M, Jordán MJ, Garrido MD, Bañón S. Effects in ewe diet of rosemary byproduct on lipid oxidation and the eating quality of cooked lamb under retail display conditions. Food Chem 2011; 124:1423-1429. DOI: https://doi.org/10.1016/j.foodchem.2010.07.102

Nutrient Requirements of Small Ruminants: Sheep, Goats, Cervids, and New World Camelids. Washington (DC): National Research Council - NRC; 2007.

Osório JCS, Osório MTM, Pimentel MA, Pouey J, Esteves R. Efeito da castração sobre a produção de carne em Cordeiros Corriedale. Rev Bras Agrocienc 1999; 5:207-210. DOI: http://dx.doi.org/10.18539/cast.v5i3.296

Padua JT, Sainz RD, Prado CS. Efeitos de grupos genéticos, castração e anabolizante no desempenho e nas carcaças de bovinos de corte, Proceedings of the 38 a Reunião anual da sociedade brasileira de zootecnia, 2001 JUL 27, Piracicaba, Brazil. Brazilian Society of Animal Science; 2001.

Pinheiro RSB, Sobrinho AGS, Souza HBA, Yamamoto SM. Quality of meats from cuts of lamb and adult sheep carcasses. Rev Bras Zootec 2009; 3598:1790-1796. DOI: http://dx.doi.org/10.1590/S1516-35982009000900022
Pinto APP, Furusho-Garcia IF, Leopoldino Júnior I, Olalquiaga JR, Gomes N, Garcia I. Performance and carcass characteristics of lambs fed diets with fat and vitamin E. Rev Bras Zootec 2011. 40:2911-2921. DOI: http://dx.doi.org/10.1590/S1516-35982011001200039

Ribeiro ELDA, Silva LDDF, Rocha MA, Mizubuti IY. Desempenho de cordeiros inteiros ou submetidos a diferentes métodos de castração abatidos aos $30 \mathrm{~kg}$ de peso vivo. Rev Bras Zootec 2003; 32:745-752. DOI: http://dx.doi.org/10.1590/S1516-35982003000300027

Regulamento da Inspeção Industrial e Sanitária de Produtos de Origem Animal (RIISPOABrazil). Brasília. Decreto n 9013. 2017, 62(1).

Rodríguez AM, Castells D. Montevideo. Crecimiento y tipo de res de corderos Corriedale sin castrar, castrados y con ascenso inducido de los testiculos. Produc Ov 1991; 4:139-145. DOI: http://dx.doi.org/10.18539/cast.v11i3.1244

SAS Institute. Statistical Analysis System. Cary (NC): User's Guide; 2003.

SIARCS. Sistema integrado para análise de raízes e cobertura do solo. EMBRAPA. Centro Nacional de Pesquisa e Desenvolvimento de Instrumentação Agropecuária (São Carlos, SP), Lúcio André de Castro Jorge e Silvio Crestana. Patente de Privilégio de Invenção BR INPI n.004276 n.5.519.111. dez. 1996

Silva TPD, Júnior SCS, Santos KR, Marques CAT, Torreão JNC. Thermoregulatory characteristics and weight gain of Santa Inês lambs in the southern state of Piauí in the dry-water transition period. Rev Agrar 2013:198-204.

Teixeira PPM, Silva ASL, Vicente WRR. Castraçao na reprodução de ovinos. Rev Científica Eletrônica Med Vet 2010; 14.

Turino VF, Susin I, Pires AV, Mendes CQ, Morais JB , Júnior RCO. Casca de soja na alimentação de cordeiros confinados: desempenho e características da carcaça. Ciência Anim Bras 2012; 8:55. DOI: http://dx.doi.org/10.1590/S1516-35982008001100022 
Vergara H, Gallego L. Effect of type of suckling and length of lactation period on carcass and meat quality in intensive lamb production systems. Meat Sci 1999; 53:211-215. DOI: http://dx.doi.org/10.1016/S0309-1740(99)00059-5

Yamamoto SM, Silva Sobrinho AG, Pinheiro RSB, Leão G, Castro DPV. Inclusão de grãos de girassol na ração de cordeiros sobre as características quantitativas da carcaça e qualitativas da carne. Semina: Ciênc Agrár 2013; 34:1925-1934. DOI: http://dx.doi.org/10.1590/S1519-99402016000200010 